University for Business and Technology in Kosovo

UBT Knowledge Center

Oct 27th, 1:30 PM - 3:00 PM

\title{
Sale of Personal Successful in The Context of Marketing
}

Hamëz Rama

University for Business and Technology, hamez.rama@ubt-uni.net

Follow this and additional works at: https://knowledgecenter.ubt-uni.net/conference

Part of the Business Commons

\section{Recommended Citation}

Rama, Hamëz, "Sale of Personal Successful in The Context of Marketing" (2018). UBT International Conference. 310.

https://knowledgecenter.ubt-uni.net/conference/2018/all-events/310

This Event is brought to you for free and open access by the Publication and Journals at UBT Knowledge Center. It has been accepted for inclusion in UBT International Conference by an authorized administrator of UBT Knowledge Center. For more information, please contact knowledge.center@ubt-uni.net. 


\title{
Successful Personal Sales in the Marketing Context
}

\author{
Prof.Doc.Dr.Hamëz Rama \\ Professor at UBT University College \\ Addres: Street “ U Ç K “-a, n.n. \\ 21010 Rahovec, Kosovo \\ hamez.rama@ubt-uni.net \\ hamezrama@hotmail.com
}

\begin{abstract}
Huge development of science and technology at the beginning of this century has affected directly in economic development, the appearance of a rich offer on the market the increase in living standards, the contemporary and quality way of life, etc., personal sales gave a new dimension, quality and new content. By leaving behind the way the traditional sales distribution, the new concept of sales, ranging from sales through the slot, mail, shopping centers, internet "e-bay", etc. introduced radical changes to this concept in communication between seller and buyer. These qualitative changes not only in the spatial view, time of the product, but also in the way of communication, the creation of purchasing and selling atmosphere and in escorting customer satisfaction after the purchase.

The advantage of the application of personal sales, we will mention the possibility of special treatment of any client or customer, the focus of attention on it and providing a flexible enough information. We are dealing with a very relations active between seller's-buyers, which increases the chances for decision-making for purchase. Personal sales are focused in the targeted market focused and considered as a district closing the additional impact advertising towards the market, this, because through their actions clarified all without leaving the stated in advertising, eg. price, guarantee for the product, way of using, maintenance, etc.

Therefore, successful personal sales the contemporary process of selling is one of the important forms of communication with the market. It has not lost its significance within the contemporary forms of sales, but its role has changed and has grown in a qualitative sense, in terms of consumer information and advice.
\end{abstract}

Keywords: sale, market, communication, buyers, marketing. 


\section{Introduction}

Conducting sales effective manner It is very important for any business.If you work as a seller and you are in contact with the buyer, or you are a sales team manager, achieving very good results will not depend solely on knowing your product but how your success will depend even by the recognition of your buyers and communication skills that will help you a lot the realization or completion of the sales act.

Successful sale includes every aspect of the sales process, ranging from the provision of appropriate advice which will affect the approach of buyers, personal organization, identifying customer needs, and to build essential skills such as: presentation and discussion with buyers.

So, successful personal sales is the direct sale where seller and buyer meet, which characterizes with a high degree of communication flexibility, with specific orders and with necessary clarifications for all, the characteristics of products and services.

Through personal sales two important activities are carried out such as:

- Promoting the product, and

- Realization of the act of sale.

Particular role in personal sales activity he plays a person involved in the process which must be a good expert in recognizing the content of the product and the services, have high communicative skills, dexterity to explain the offer but also to influence positively the decision of the buyer. 


\section{Preparing for Sale, Objectives for Success}

Selling is the basis of every success in the business. It sets the foundation for a successful business by following the principles and long-term practices, and relying in the personal skills of sales personnel.

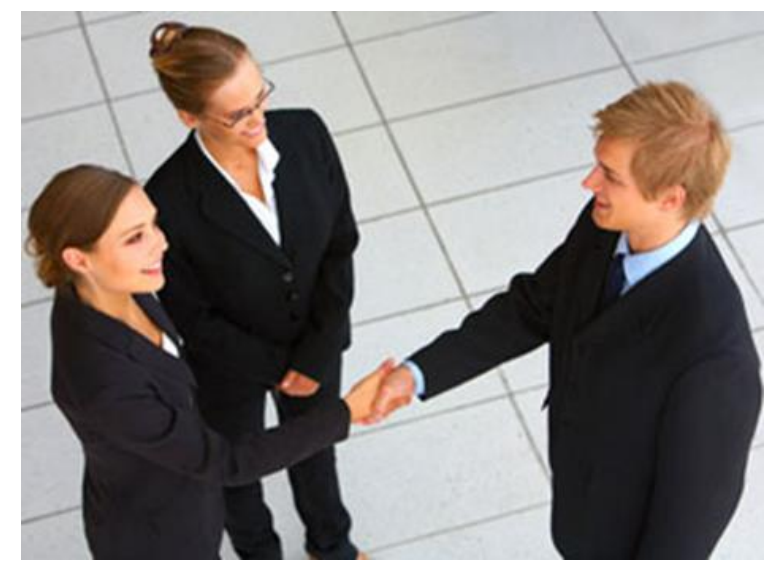

Photo 1. Preparing for sale, objective for success

In successful sales, really everybody wins. Good sellers make deals with their buyers. Not good sellers, their buyers offer you bad deals. Consumers who feel they have purchased a product or proper service, they will be satisfied, and would like to go back to buy more.

During the sale of the products or services by the domestic(sales representative) of the company, realized profit. Profit for domestic respectively for the company It is not just selling products or services, he must also fulfill these two conditions:

- Creating satisfied buyers, and

- Realization of a satisfactory profit for the company.

The stattisfactation rate is supported in the real strength of the offered and scattered proposals. Assessing the effectiveness of sales on the basis of sales volume it is easy to calculate, but that can offer a price sale or a large payment period which ultimately makes this non-profitable sale. 


\section{Obtained Confidence}

Selling, at times, may seem like a form of confrontation, this shows that many sellers are difficult to realize this process or when they influence to realize it. To successfully realize personal sales you always have to replace your feelings of fear and failure with positive hopes for success and then the sale will be a pleasant experience.

\subsection{Presantation of Clear}

If you're nervous you can hurry to hurry up your sales. Direct the sale properly with constant rhythm and always rely on positive hopes for success.

Speak frantically and with sound to hear you all and avoid stuttering. Look at others who hear you to understand how distributed your speech, your order, in a proper manner and address them sometimes, during your speech with any questions about what you said.

Also, you should be careful of the appearance and your behaviors because they have a direct connection in creating a credibility to potential buyers. Dress carefully, adjust your hair well, looking straight to the eye or a handshake greeting will send a good message to buyers.

\section{Agrements with Byers}

Understanding the attitude of buyers is the key to increasing sales. Make research into identifying potential buyers, maximizes contacts with buyers, and keep good relationships with them.

\subsection{Identification of the Types of Byers}

The decision to purchase, to buyers is influenced by many circumstances, not just from competition prices as generally assumed, while differently, have the needs for the development of their business.

Make an effort in building customer profiles, where they will express their most attractive features, and keep in mind fulfilling the basic needs of buyers they will be pleased to purchase the products or services from you.

\subsection{Identification of motivations}

Your goal should be to harmonize your sales strategy, motives and different situations of buyers.

Your buyers will accept your offer whether it will enable you solve problems the immediate or improving their business performance.

Some types of buyers may be motivated by security needs and will seek to guarantee their seriousness. Buyers belonging to that group guided by wishes will buy those products that will meet their wishes, while in those buyers where the ego is the main motivator will want to have the best available product. 


\subsection{Finding Purchasers}

The seller may lose much time talking to someone that there is no budget to purchase, or who lacks the authority to say yes to a proposal that is sold. Sometimes you may know who the recipient of the decision is, but you may not be able to have direct contact with it, the solution is to insist on the realization of this contact.

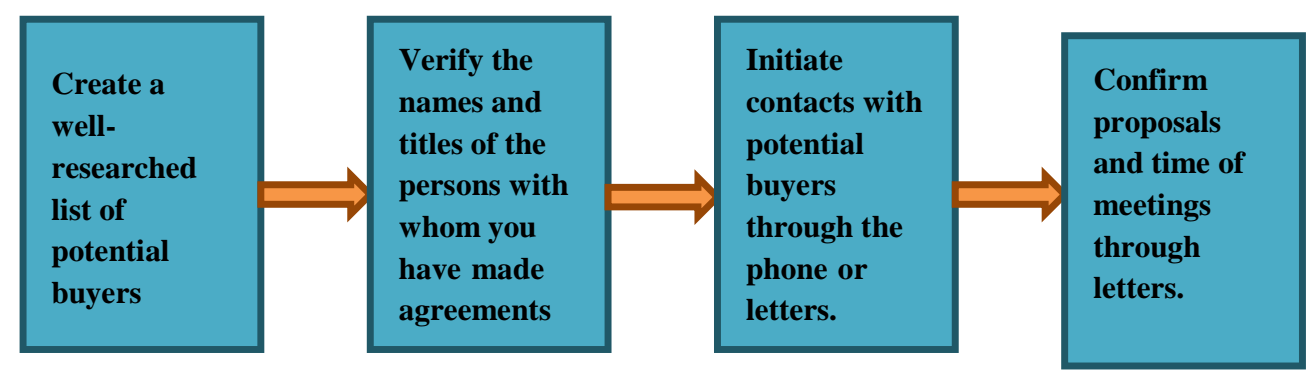

Fig. 1. Contact with the buyer

You can discover more about your potential buyers without leaving from your desk. At the same time you have identified the potential client, spend time learning the needs and his or her desires, given the possibility of constant sales growth.

Your work desk is where you can start with questions for potential buyers. After the questions, mark where they can be found information in your personal files, Web pages relevant, or through personal contacts, to make your research effective.

\section{Efective Comunication}

Your main goal during communication with buyers is to secure the sale. Ideally, the meeting should result in the show of pleasure from both the parties. Open and honest communication is the key to success.

You must be trustworthy to the buyer if you want him to trust you. Eye contact and body attitude play a role very important in building good relationships. Smiled at and use the non-threatening gestures.

Look at the buyer's attitude to inform you about the reaction to you and improve your behaviors in accordance with him. Ask questions and carefully read the notes on intentions and complaints because they can offer you more knowledge about the buyers needs. 


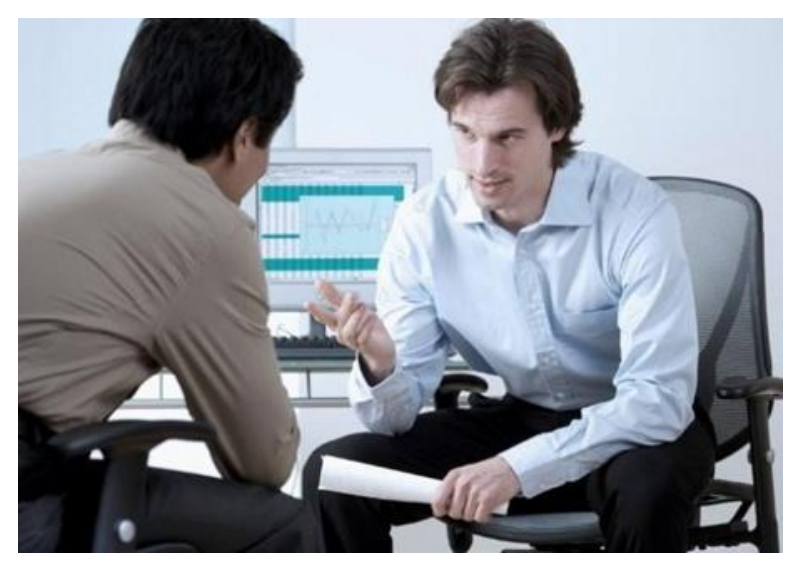

Photo 2. Effective communication with the client

\section{Motivation of buyers}

The benefit of potential buyers on your side means engagements to identify what motivates him or her. This will be accomplished more easily when the buyer is more sociable and more communicative. If the buyer initially expresses an objection try to overcome this obstacle between you.

There are two ways of behavior to motivate the buyer:

First: You stand in the position of any other person, speak honestly and use friendly conviction when the buyer looks uncertain. Start right away with themes if ever is lack of time or impatient.

The second: Use the strength of your character to acquire the consent of the buyer. The best way to motivate the buyer is the combination of these two techniques.

\section{Cultural differences of buyers}

When talking to buyers of different countries you need to know about the different cultural factors.

\section{For example:}

Japanese buyers, can hardly be evaluated by others. They may speak very little during the meeting, but can suddenly show readiness for any deal.

François Buyer, maybe you have to wait long for him to finish lunch and then switch to the topic.

The English buyer, he appears as a conversation together that offers and receives, but often ends up as an enthusiasm for your offer but it may happen that you do not accept it. 


\section{Providing Services to Costumers}

Treat sales and sales services as a single. Considering sale as the first line of activities and go after the needs of the buyers, providing what they want, when they want, and how they want it and should follow the sale to make sure they are satisfied with the buyer.

Sales services should not end with the sale. The better you identify and address the needs of buyers the more they will have a positive impact on their loyalty.

Always, after the realization of the sales act ask that "Is the buyer satisfied" and "Will he or she buy it again?" If the answer is no, find the reason why and what can be done in solving this problem. Create habits that after sales contact with your buyers, to understand if they are happy.

\section{Statisfaction of Costumers}

You can not at the same time to satisfy the needs of all customers. But you, when you do not have to stop in achieving this goal. Identify what they are, the needs of buyers and then find out if these needs are encountered from a constant monitoring of buyers' reactions.

Determination of prioritites: do not get the price as the first priority. Sellers often hurt profit by it taken this as a priority. Buyers may have a different number of the priorities in their list, such as: delivery time, technical support, etc. If you have researched what the buyers want the most and how products or services are ranked of your company compared to those of the competition, and then successful sales will be considerably easier.

Keeping of buyers: The only sure way to understand whether you have met your buyers' needs is that you ask them. Invite a group of your buyers, to tell you what would make them more attractive your products or services. You submit questionnaires and call the buyer personally to get answers from them.

Use the comments from other buyers contact routinely with staff which can provide you with useful information. Above all you make it clear to buyers that you want their comments and that you will use them to improve the products and services of the company.

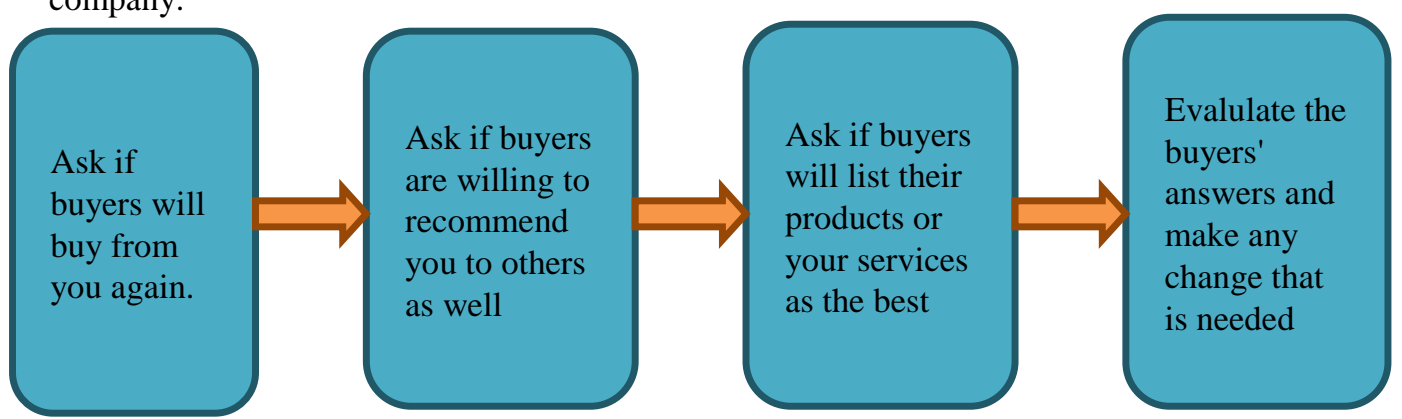

Fig.2. Submission of questions substantially to consumers 


\section{Realizing the Successful Sales}

Effective selling includes planning and strategy itself. Your strategy may initially include group presentation or an advertising campaign via mail, but all sales are ultimately dependent on purchasing skills. Sales activities require a military style of planning to achieve an increase of successful the sales quota. Buyers must be clearly identified, market to be involved in an appropriate manner to retailers in certain locations and sales should be tailored to the needs of buyers.

There's no such thing as a born salesperson. Sellers of big sales, made it look easy, but superior performance usually indicates a sellers has taken the time to hone their skills and is constantly iterating to better help their prospects.

Whether you're a first-time or looking to get back to the basics, these tips are the seven essential pillars of successful selling.

1. Identify goals

2. Recognize sales as a process

3. Identify business pain(problems)

4. Measure every step

5. Sell to the right people

6. Embrace team selling

7. Conduct call reviews

Adjustment of the strategy: if you are selling a product that exists or launching of a new product, strategy of successful sales should be based on the overall product analysis, market and competition. The purpose of your strategy may be to find new buyers, or strengthening relationships with existing buyers. But before you trust your sales resources, sales leader, think about the size of the market, its potentials and competitive forces from other organizations. Initially you have defined your market, but make sure your wrestlers sales have covered the space in which your potential buyers are.

\subsection{Using the AIDCA Strategy}

The designation of AIDCA strategys consists of the initials of words:

$\mathrm{A}=$ Attention

$\mathrm{I}=$ Interest,

$\mathrm{D}=$ Desire,

$\mathrm{C}=$ Conviction

$\mathrm{A}=$ Action

These are five stages that will guide your potential buyer in the continuation of increasing opportunities for a successful sale. Utilizing the AIDCA strategy offers you the opportunity to provide a form and leadership of advertising, and makes your proposal understandable and attractive to your potential buyer. 
The AIDCA strategy initially draws attention to the buyer, then encourages interest and converts interest in the desire, for the product or your service where it then creates obedience which would result in action - ie selling your product or service.

ATTENTION(attracting of attention): you need to get the buyer's attention so that you can make the sale. Attention may be attracting by an act of singing or dancing, by a stunning proposal, or by a presentation of an influential or admired person. Whichever technique is used, your goal is to be perceived by buyers. You should take advantage eyes and ears of buyers before you win, mind, heart and their portfolio.

INTEREST(growth of interest): Change the attention interest. It depends on the understanding and perseverance of the buyers. This is a promise that potential purchasing will really satisfy the needs of buyers. For example. the saying " What I have to offer you, I will be halved telephone bill " so it is a kind of proposal that will interest you everybody. With such statements will not be realized sales, but this statement will be an incentive for the buyer that he ask for further information on the products or services.

DESIRE (inspiration of desire): attention and interest are not enough to achieve sales. The buyer must be driven in a state of desire. An ad in the press draws attention, the details about the attendance areas awaken interest, and pictures with brochures sent by tourist agents inspire desires. Most specifically as a price discount or preferential payment projects provide additional inspiration to buyers. Basic needs are more important but embellishment can touch the scale and some cases may seem to be the main object of desire.

CONVICTION(creation the conviction): the buyer must make that conclusion to result in purchase, from you and only from you. Dduring the advertising you need to present a "Unique sales proposal". This is an attribute that shall persuade buyers that your product or service changes and is better than others. For example, compare tourist trips with other alternatives the most expensive, encourage the buyer's conviction that the purchase decision is correct. So make an attractive insurance package or a concession in the payment method. Allow buyers to convince themselves, in comparison to be obeyed by you.

ACTION(fostering for action) : Efficiency testing is action. The famous saying saller, "Act now until there is an offer" or "Take it, it's the last" which includes two main principles: immediately and urgently. You want the buyer to order the goods immediately, so you say to him that the wrestlers will not lose forever. This situation can be artificial, but non-emergency elements can be created, the sales process may drag on, and fostering can be lost, then the whole strategy(process) of AIDCA should be repeated with a lower chance of success. 


\section{Keeping of the Sales Meeting}

Meetings, fairs, conferences, and seminars have a great value for forming a team spirit, celebrating successes on the progress, developing relationships with buyers and discovery of new plans. Meetings will be effective if they allow a return of information from the sales team.

If at this meeting the buyer has said a "yes" then what do we do now? You need to connect. You need to inspire. And you need to drive action.

Following these seven steps will help you get there:

1. Develop rapport,

2. Review the meeting premise,

3. Share a tentative agenda,

4. Include your buyer in the agenda setting,

5. Ask to be interrupted

6. Tell a convincing story,

7. Shift to inquiry and collaboration.

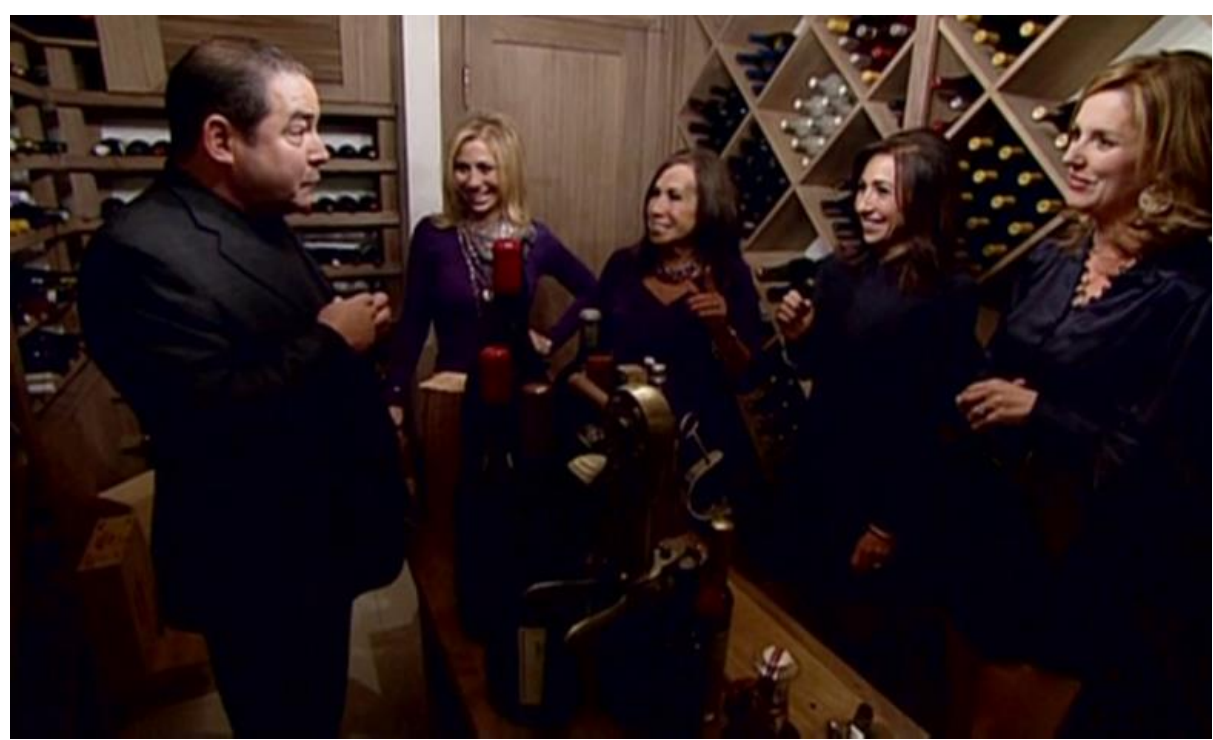

Photo 3. Successful personal sales meetings 


\section{Conclusions}

Consider, successful personal sales is part of the so-called "4P" marketing tools, through which enterprises develop development policies and enterprise strategy to determine the pattern in which direction will go to the enterprise and where he wants to achieve.

Promotional activities respectively promotion as the 4th MIX marketing tool, is the umbrella of personal sales and a very important factor, provide access to the designated market segment, the target customer, and direct customer communication and by the customer, we provide feedback.

\section{Recommendations}

1. Establishment of professional capacities in the field of marketing,

2. Applying marketing concepts,

3. More promotion of products, successful personal sales, and promotion of sales, and

4. Use strategy AIDC, in achieving the enterprise objective. 


\section{Reference}

1. Dr.Nail Reshidi: "Promotion - Advertising and Personal Sales", Riinvest, Pristina, 1996

2. Artan Xh.Duka \& Niko A.Pano: "Promotions", Shblu, Tirana, 1999

3. Dr.Robert Heller: Selling Successfully.

4. Dr. Nexhmi Rexha \& Dr. Nail Reshidi: "Marketing", RMSS, Pristina, 1998.

5. Dr.Ali Jakupi: "Marketing", AAB, Prishtina, 2008.

6. Dr.Nexhmi Rexha: Dictionary of English-Albanian business terminology.

7. Ramadan Hysa: English - Albanian Dictionary

8. Oxford: Advanced Lerner's Dictionary.

9. https://blog.hubspot.com/sales/keys-to-successful-selling-for-the-first-time-sales-rep

10. https://www.google.com/search?q=Strategy+AIDCA\&source=lnms\&tbm=isch\&sa= X\&ved=0ahUKEwiK8IHJ4vfeAhWviIsKHW5YBkwQ_AUIDigB\&biw=1366\&bih= 657\#imgrc $=$

11. https://www.rainsalestraining.com/blog/7-steps-to-a-successful-sales-meeting 